\title{
妙高高原におけるブユ幼虫駆除の研究
}

\section{Studies on the control of blackfly in Mt. Myōkō Area}

\begin{tabular}{|c|c|c|c|}
\hline 雄 ${ }^{11}$ & 東修利交 ${ }^{11}$ & 渡辺藤市 ${ }^{11}$ & 塩㥓 琵 ${ }^{1}$ \\
\hline & 学 ${ }^{2}$ 鈴 才 & $\begin{array}{l}\text { 猛 }^{2)} \text { 林 } \\
\text { 未 正和 }\end{array}$ & 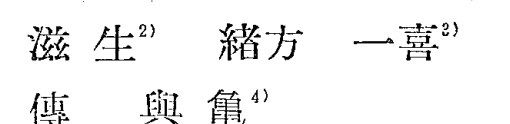 \\
\hline
\end{tabular}

Akio Watabe, Toshibumi Tōjō, Tōichi Watanabe, Kiyoshi Shiozaki, Michisuke Kubota, Manabu Sasa. Takeshi Suzuki, Shigeo Hayashi, Kazuki Ogata, Kisaburō Yamagami, Masakazu Kiyosue and Tomohisa Den

\section{Iまえがき}

我が国に执いて，本格的なブニ駆除関する研究は， 筆者の弓ちの鈴木・緒方・林・佐从ら (1954) 飞占つて

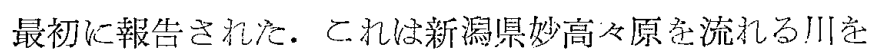
主な実験站さし，主こしてDDT老用いて，ブニ炏虫驅

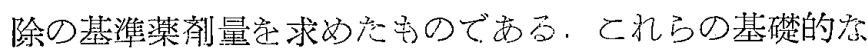
研究に引きつざき，抄高々原村が実施主体となり，高田 保健所・伝研・予研の指導巨，日本曹達株式会社二本木

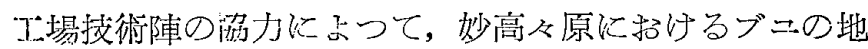
域的な駆除が広範围行行われ，相当の成果を収めを。 >に報告するのは，主として高田保健所によつて央芣さ れた研焭の成果であり，その内容は，先ず前に報告した 基磷的な研究学補迟し，更に地域的な駆除法及び与論調 查によるその效果判定突含んでいる。

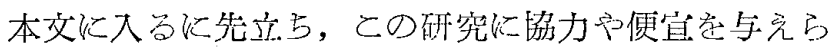
沉た新潟県衙生部長須川豊氏，及び新潟県中頚城郡妙高 及原村役場に深謝する。

\section{II 基礎的実験}

この実験牥，1954年 6 月より 8 月に至る間，新潟県中 玨城郡妙高《原村に於て実施された。本実験飞和いて, 流速測定注広井式流速計によつて抬り，又用いた薬剤 は，DDT $50 \%$ 水和剂及びD D T 40\%，リンデン $1.6 \%$ 混合ヘーストで，何れも日本曹達株式会社製造のもので ある。

1) 新潟県高田保健所 Takada Public Health Center, Niigata Prefecture

2) 東京大学伝染病研究所笴生虫研究部 Laboratory of Parasitology, Institute for Infectious Diseases, University of Tokyo

3）国立予防衛生研究所衞生昆虫部 Division of Medical Entomology, National Institute of Health, Tokyo

4) 日本曹達株式会社二本木工場 Nihongi Factory, Nippon Soda Co.

\section{DDT 撒布による有效距離の観察}

ブニ幼虫の多数樓息する水系に適宜に撒布 地点定定 め，乙>から下流の各地点で吕らかじめ幼虫の棲息状沙 学調查し，1分間流水量比対して $1.2 \mathrm{ppm}$ (或いは 1.0


ジョーロで撒布した。用いた薬凪は50\% D D T 水和剤及 び40\% DDT, 1.6\%リンデン混合ペーストである. 徒つ て後者の場合，リンデンの濃度は，1分間流水量当り $0.048 \mathrm{ppm}$ (或小综 $0.04 \mathrm{ppm}$ ) ¿なる. 撒布後 $14 \sim 24$ 時間後に，幼虫の流失状沉学観察した。ブユの棲息種は Simulium aokii 及び S. uchidai であつた. 実験及びそ の結果の概要は次の通りである.

撒布封の気温 $17 \sim 26.5^{\circ} \mathrm{C}$ ，水温 $11.0 \sim 22.0^{\circ} \mathrm{C}, 1$ 分間 流水量 $1.3 \sim 20 \mathrm{~m}^{3}$.

その結果，有效距離综，50\% D D T 水和剂使用の場合 $1.2 \mathrm{ppm}-10$ 分で約 $800 \mathrm{~m}, 40 \% \mathrm{DDT}$ Tヘースト（リ ンデン $1.6 \%$ 含有，以上同じ）使用の場合 $1.2 \mathrm{ppm}$ 10 分で $1,000 \mathrm{~m}, 300 \mathrm{~m}(+), 500 \mathrm{~m}(+), 800 \mathrm{~m}$,

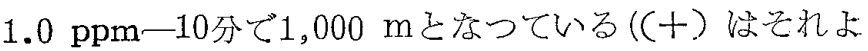
り遠い地点学観察していないこ己を示す.)

従来の報告(鉿木ら，1954；緒方ら，1956)飞よる己， 1 分閒流水量あたりD D T10ないし12 ppm の撒布によ る有效距離は，500m程度が標準已考えられているが, ての結果からみると，光れより若干長いような傾向が認 められる. しかしそれについては，更に多くのデータが 加わるまで，結論学さしひか光たい。

店招，DDTペース卜を用い，1分間あたり $1 \mathrm{ppm}$ のD D T学10分間撒布した実験以执いて, 流失した幼虫 を水中のケージで受け，そのま〉放置して生死を観察し た結果でね，5〜20㭙間内にすべて死亡するのが認めら， れた.

次に，45\%有效塩素量の高度徆粉昰，1分間流水量に 対して，10 ppm 死び $20 \mathrm{ppm}$ の濃度こして投入したさ ころ，120分ないレ 150 分経過後において,ブユ幼虫は全 
第 1 表 異なる浱度の薬剤撒布によるS. aokii 幼虫の流失状況 (1)

\begin{tabular}{|c|c|c|c|c|c|c|c|c|c|c|c|c|c|c|c|c|c|c|c|c|}
\hline \multirow{3}{*}{ 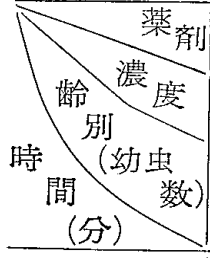 } & \multicolumn{12}{|c|}{$40 \% \mathrm{DDT}$ ペースト(リンデン $1.6 \%$ 含有 $)$} & \multicolumn{8}{|c|}{$50 \% \mathrm{DDT}$ 水和剂 } \\
\hline & \multicolumn{4}{|c|}{$1.2 \mathrm{ppm}-10$ 分 } & \multicolumn{4}{|c|}{$0.6 \mathrm{ppm}-20$ 分 } & \multicolumn{4}{|c|}{$0.4 \mathrm{ppm}-30$ 分 } & \multicolumn{4}{|c|}{$1.2 \mathrm{ppm}-10$ 分 } & \multicolumn{4}{|c|}{$0.6 \mathrm{ppm}-20$ 分 } \\
\hline & $\begin{array}{l}\text { 若 } \\
\text { 齢 } \\
\text { (16) }\end{array}$ & $\begin{array}{c}\text { 中 } \\
\text { 齢 } \\
(12)\end{array}$ & $\begin{array}{c}\text { 老 } \\
\text { 齢 } \\
\text { (13) }\end{array}$ & & $\begin{array}{l}\text { 若 } \\
\text { 䍅 } \\
(24)\end{array}$ & $\begin{array}{c}\text { 中 } \\
\text { 齢 } \\
(26)\end{array}$ & $\begin{array}{c}\text { 老 } \\
\text { 齡 } \\
(12) \\
\end{array}$ & & $\begin{array}{l}\text { 若 } \\
\text { 战命 } \\
(29)\end{array}$ & $\begin{array}{c}\text { 中 } \\
\text { 睮 } \\
(18)\end{array}$ & $\begin{array}{l}\text { 老 } \\
\text { 齢 } \\
(7) \\
\end{array}$ & 率 & \begin{tabular}{|l} 
若 \\
齢 \\
(13) \\
\end{tabular} & $\begin{array}{c}\text { 中 } \\
\text { 柃 } \\
(12)\end{array}$ & $\begin{array}{c}\text { 老 } \\
\text { 齢 } \\
(\mathbf{9}) \\
\end{array}$ & & 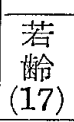 & $\begin{array}{c}\text { 中 } \\
\text { 龄 } \\
\text { (13) }\end{array}$ & $\begin{array}{c}\text { 老 } \\
\text { 龄 } \\
(7)\end{array}$ & \\
\hline 5 & & & & $\%$ & & & & $\%$ & 2 & 1 & 1 & $7.1^{\%}$ & & 1 & 1 & $\begin{array}{l}\% \\
.0\end{array}$ & & 1 & & 5.4 \\
\hline 10 & & 2 & 2 & 9.6 & 2 & 2 & 2 & 10.9 & 5 & 3 & 2 & 17.8 & & 2 & 1 & 8.8 & 1 & 2 & 1 & 10.8 \\
\hline 15 & 3 & 6 & 7 & 39.0 & 7 & 8 & 4 & 40.0 & 10 & 5 & 4. & 33.9 & 1 & 4 & 1 & 17.6 & 3 & 4 & 2 & 24.4 \\
\hline 20 & 6 & 9 & 10 & 60.0 & 14 & 13 & 7 & 65.0 & 16 & 8 & 6 & 53.5 & 6 & 7 & 3 & 47.0 & 6 & 6 & 3 & 40.5 \\
\hline 25 & 10 & 11 & 12 & 80.2 & 18 & 17 & 9 & 85.0 & 18 & 11 & 6 & 66.0 & & & & & & & & \\
\hline 30 & 12 & 12 & 13 & 90.2 & 21 & 22 & 11 & 93.0 & 20 & 13 & 7 & 75.0 & 9 & 9 & 6 & 70.0 & 9 & 9 & 4 & 60.0 \\
\hline 35 & 14 & & & 95.1 & 23 & 25 & 12 & 96.0 & 25 & 16 & & 89.0 & & & & & & & & \\
\hline 40 & 16 & & & 100 & 24 & 26 & & 100 & 29 & 18 & & 100 & & & & & 13 & 10 & 6 & 78.0 \\
\hline 50 & & & & & & & & & & & & & 11 & 10 & 7 & 79.0 & 16 & 12 & 7 & 84.6 \\
\hline 110 & & & & & & & & & & & & & 13 & 12 & 9 & 100 & 17 & 13 & & 100 \\
\hline
\end{tabular}

第2 表 異なる濃度の薬剂撒布によるS. aokii 幼虫の流失状況 (2)

使用薬侴： $40 \% \mathrm{DDT}$ ペースト(リンデン $1.6 \%$ 含有)

表中の数字は $50 \%$ 流失に要する時間 (分) 示す

\begin{tabular}{|c|c|c|c|c|c|c|c|c|c|c|c|}
\hline \multirow{2}{*}{$\begin{array}{l}\text { 撒布時 } \\
\text { DDT 間 (分) } \\
\text { 濃度 } \\
\end{array}$} & \multicolumn{3}{|c|}{ 若 齢 } & \multicolumn{3}{|c|}{ 中 齢 } & \multicolumn{3}{|c|}{ 老 齢 } & \multirow[b]{2}{*}{ 計 } & \multirow[b]{2}{*}{ 平均 } \\
\hline & 10 & 20 & 30 & 10 & 20 & 30 & 10 & 20 & 30 & & \\
\hline $0.4 \mathrm{ppm}$ & 10 & 9 & 12 & 20 & 20 & 10 & 9 & 12 & 8 & 110 & 12.2 \\
\hline 0.6 & 15 & 11 & 7 & 12 & 20 & 7 & 11 & 8 & 7 & 98 & 10.9 \\
\hline 1.2 & 10 & 10 & 10 & 10 & 10 & 10 & 5 & 8 & 7 & 80 & 8.9 \\
\hline 2.4 & 7 & 4 & 9 & 9 & 10 & 10 & 7 & 6 & 7 & 69 & 7.6 \\
\hline 計 & 42 & 34 & 38 & 51 & 60 & 37 & 32 & 34 & 29 & & \\
\hline 総 計 & & 114 & & & 148 & & & 95 & & 357 & \\
\hline 平均 & & 9. & & & 12. & & & 7 & & & 9.9 \\
\hline
\end{tabular}

く流失しないのが認められた。

\section{2. 藥剂の散布濃度及びブユ幼虫の齢别と流失時間の 関係}

次に，薬㶡の撒有濃度をかえフブニ幼虫の齢別によつ て流失時間定観察した。

第1表のうち，DDTペーストを用いたものは，気温 $: 25^{\circ} \mathrm{C}$, 水温 $15.0^{\circ} \mathrm{C}$ に抬いて 1 分間流水量 $0.18 \mathrm{~m}^{3}$ の川で, 又D D 水和剂字用いたのは, 気温 $15.0^{\circ} \mathrm{C}$, 水温 $12.0^{\circ} \mathrm{C}$, 1 分間流水量 $0.1 \mathrm{~m}^{3}$ の川で行つたむのて, 咬象のブニ



流失状況の観察地点は，何れも薬郕撒布地点より約 20 $\mathrm{m}$ 下流で，観察法は，ビーカー定用いて水面上から直接 水幼虫を観察するいわりる算定法である。

第 1 表の結果からみる己，1)一般に䕁珮濃度が高い程
流失時間が短办い傾向は認力られるにしても，それ程明 ら亦なものではな。

2）ＤＤＴペースト学用いたこきは，濃度乞撒布時間 のざの組合世に秐いてす，40分後には，すい゙て幼虫が流 失して招り, 又DDT水和剂では50分ないし 110 分後に

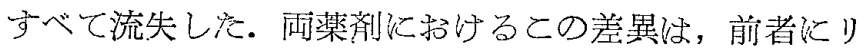
ンデンを含んでいるためをも荅えられるが，又薬剤の組 成による水中の分散性，沈降性の相違む無視することが 出来ないであろう。

3）幼虫の歯別によつて流失㭙間学比較した場合，老 柃がはやく流失する傾向が認められる。

てれらの関係について更に詳細な実験学行つた結果が 第2 表である. 方法彷招〉む致前項の実験に準じている が, 流失状況以，撒布後 5 分每に算定法によつて流失数 
を調查し，最初の幼虫数の半数が流失したをき学もつて 実験学打与きつた。

この結果による上, 半数が流失するるでの時間ね, 最 短が 4 分, 最長が 20 分で, 平均は 9.9 分である. 従つ て，撒布時間の長短怡，乙の結果にそれ程大きな影響を 与充ていない上考える。

第 2 表の結果学玉とめると次の如くなる。

1) 薬剤濃度 ( 1 分間流水量に対して $0.4,0.6,1.2$ 及び $2.4 \mathrm{ppm})$ のそれぞれに対する50\%流失時閒の間以 は危険摔 $5 \%$ で有意な差がある. 又, 楽剂濃度の対数に 逆比例して, 直線的に流失時間が短方くなる (第 1 図).

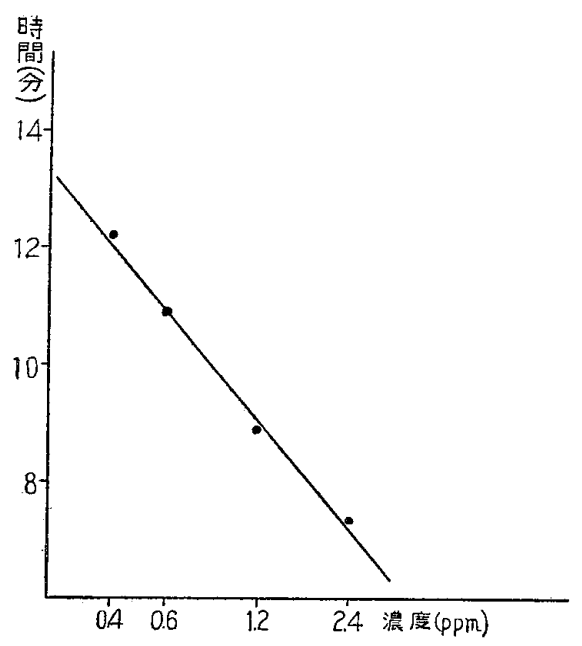

第 1 図 县剤濃度とブニ幼虫流失時間の関係


老秢に比較して，流失時間が長い。（危険率 $5 \%$ で有 意)

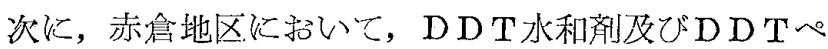
一スト妾用いて，ブニ幼虫の流失状況学調查したをころ DDT $2.4 \mathrm{ppm}-10$ 分撒布で S. aokii 站90分以内《す べて流失したが，アシマダラブユ S. japonicum は流失

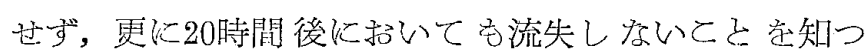
た. 度抬， $2.4 \mathrm{ppm}-20$ 分撒布では, S. japonicum 福 40分ですべて流失した。上結果から，S.japonicum 注，S. aokii に比較してかなり抵抗が強い上弓に見受け ら记る。

\section{III 地域的駆除の実験}

地域的駆除の実施地域经前記炒高々原村であり，その 概要は次の通りである。

面積 $24 \mathrm{~km}^{2}$, 標高 $500 \sim 800 \mathrm{~m}$, 駆除対象河川約50, 延 距離 $38 \mathrm{~km}$ ，户数 1170 戸，人口5937人(昭和 25 年国勢調查 による).

\section{1. 実施地域におけるブユの分布}

この地域に招いて採集されたブュの種類は 11 種で，乙
の種名治次の通りである。（カッコ内经採集地学示す）。

Prosimulium yezoense (燕), Cnephia mutata (燕), Simulium uchidai (燕, 赤倉), S. yamayaense (赤倉), S. aokii (燕, 赤倉, 池ノ平, 杉ノ沢, 二俣), S. ornatum (赤倉, 二俣), S. nacojapi (杉ノ沢), S. japonicum (燕, 赤倉, 池八平), S. decorum (杉ノ沢), S. venus. tum (赤倉, 池八平, 杉八沢), S. rufibasis (池)平, 杉ノ沢).

月別に少高及原一带の各河川飞於て幼虫, サナギの採 集学行い, 各種の出現季節的消長空調查した. その結果 P. hirtipes では，11月ょり5月に亦汀幼虫，5月にサ ナギ，引続き成虫の活動が見られた，之の後夏の間は卵 であるらと考六られるが採集確認するととは出来なかつ た.S. ornatum 以殆ざ全年にすたつて出現が少られた。 S. japonicum は $4 \sim 9$ 月, S. aokii uchidai $8 \sim 1$ 月に加採集出来たが, その他の種類 上己もに採集数む少く，的確にその消長定つかむここが. 出来なかつた。

\section{2. 駆除実験の概要及び実施成綪}

駆除については，新潟紧ブ二駆除実施要領により，村 役場, 村連合青年団孞駆除班定編成し，(1 班 3 名, 8 二 班）筆者らの指導及び日曹二本木工場協力の下に実施さ れた。実施期間结 5 月から11月末での7カ月間で, 每月: 1 回, D D T 水和剤或いほD D Tペース卜を撒布した。 薬剂㤝 1 分間流水量に詨してDDT10 ppm にあたる稀 粎液を投入したものである。

な扮，1955年 4 月下旬以行われた，駆除実施前の基礎 調査は, 次の項目学んでいる.

1）刘象地区全域についての概要図作製. 2) 各班担 当地区別発生源見取図の作製．3）ブユ成虫，幼虫，蛹 の発生状態の調查, 採集標本の作製, 同定.4）流水量: の測定，所要薬㶡量の算定，及び撒布地点の選定５） 気象条件, 環境状沉調査.

薬剂撒布状況注第 3 表に示す。

\section{3. 駆除效果判定及び被害狀況}

1955年 5 月 31 日(第 1 回)，7月16日（第 2 回）及び 9 月28日（第 3 回）の 3 回飞わたり，炒高中学校の生徒 5 00名中から, 部落人口に深ざ比例した人員学無作為に抽 出し, その生徒（或いはその家族を合めて）に対してブ ニによる刺焧状況の調查学行つた。

第 1 回及び第 2 回々，それぞれ駆除実施地域及び非実 施地域に対して, 生徒数 153 名, 44 名, 家族全数 907 名，266 名に対して，前年及び本年の刺咬の有無学， 調查用紙を配布して調查した. その結果学 4 表《示し た。これによれね゙，非実施地域では前年飞比較して今年 の方が刺された人の率が多いのに拘らず，笑施地域で 
第 3 表 地域的駆除の薬㕮撒布状況

\begin{tabular}{|c|c|c|c|c|c|c|c|c|}
\hline 回数 & 1 & 2 & 3 & 4 & 5 & 6 & 7 & 棓 \\
\hline 月 別 & 5 月 & 6 月 & $7 \sim 8$ 月 & 9 月 & 10月 & 11月 & 11 12月 & \\
\hline 撒存日数 & 4. 日 & 5 日 & 5 日 & 6 日 & 6 日 & 5 日 & 4. 日 & 35日 \\
\hline 撒布個所 & 55 & 76 & 63 & 63 & 60 & 60 & 60 & 434 \\
\hline  & $\begin{array}{c}50 \% \\
\text { DDT } \\
\text { 水和到 } \\
40 \% \\
\text { DDT } \\
\text { ペースト }\end{array}$ & $\begin{array}{c}40 \% \\
\text { DD'T } \\
\text { ペースト }\end{array}$ & 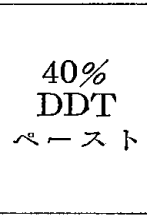 & $\begin{array}{l}\text { D0\% } \\
\text { DDース } \\
\text { ペースト }\end{array}$ & $\begin{array}{c}40 \% \\
\text { DDT } \\
\text { ペースト }\end{array}$ & $\begin{array}{c}40 \% \\
\text { DDT } \\
\text { ペースト }\end{array}$ & $\begin{array}{c}40 \% \\
\text { DDT } \\
\text { ペースト }\end{array}$ & $\begin{array}{c}50 \% \\
\text { DDT } \\
\text { 水 和 削 } \\
40 \% \\
\text { DDT } \\
\text { ペースト }\end{array}$ \\
\hline 撒布数量 & $\begin{array}{l}4,889 \\
9,100\end{array}$ & 11,878 & 12,800 & 10.950 & 12,900 & 9,300 & 9,280 & $\begin{array}{r}4,889 \\
76,208\end{array}$ \\
\hline $\begin{array}{r}\text { 所要金額 } \\
\text { (四) }\end{array}$ & $\frac{2,787}{5,214}$ & 6,780 & 7,296 & 6,242 & 7,353 & 5,301 & 5,290 & $\begin{array}{r}2,787 \\
43,476\end{array}$ \\
\hline $\begin{array}{c}\text { 延從事人員 } \\
\text { 人. }\end{array}$ & 20 & 20 & 20 & 24 & 24 & 10 & 8 & 126 \\
\hline
\end{tabular}

第 4 表 地域的駆除の効果についての与論調查

\begin{tabular}{|c|c|c|c|}
\hline & \multirow{6}{*}{$\begin{array}{l}816(90.0 \%) \\
532(58.7 \%) \\
338(37.3 \%)\end{array}$} & \\
\hline \multicolumn{2}{|c|}{$\mathbb{S}^{\infty}$} & & \\
\hline \multicolumn{2}{|c|}{ 調 查 事. 項 永族全数 } & & \multirow{4}{*}{$\frac{\text { 非実施地区 }}{44}$} \\
\hline \multirow{3}{*}{$\begin{array}{l}\text { 刺されれ } \\
\text { 人の数 }\end{array}$} & & & \\
\hline & & & \\
\hline & 本年 $(\mathbf{I I})$ & & \\
\hline
\end{tabular}

註調查実施日 I：1955年 5 月 31 日

II：1955 年 7 月 16 日

蛙，明らかに今年の方が少い。又箱 1 回の調查より，第 2 回の調查の方が率が小さいととも認めら记る。先扮， 実施地域已非実施地域の間で，第 1 回と第 2 回に分けて 百分率の差を検定したをころ，何れも1\%の危険率で， 実施地域の方が刺された人の率が有意飞少いことが認め られた。

第 3 回の調查沵, 実施地域の生徒 159名, 非奏施地域
の113名定刘象に，上肢々下肢の刺咬数孛比較したもの である。

その結果，上肢下肢の刺㕮総数の平均值活実施地域，

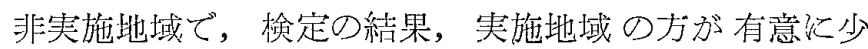
い. 更《実施地域定 $\mathrm{A}$ 地域 (赤倉・新赤倉・田切二俣), $\mathrm{B}$ 地域（池の平・妙高・関川， $\mathrm{C}$ 地域 (毛福坂・田中) の3地域に分壮て比較したところ，A 11.12，B9.14, $\mathrm{C} 5.34$ で，倹定の結果， $\mathrm{B}$ こ $\mathrm{C} ， \mathrm{~A}$ こ $\mathrm{C}$ の閒《は有意な 差が認的られたが，A上Bの閒に淙有意な差が認められ なかつた。

次に，刘象全生徒の272 名につ总，上肢下肢の刺咬数 定比較した己ころ, 上肢1.41, 下肢 $13.5 て ゙$, 有意に下肢 の方が多く, 又性別（男 129名，女 142名）についての 比輘では，男17.1，女12.0で有意に男の方が多い，

な和，第 1 回の調查比括いて，家族学含好を全員1173 名以一定の調查用紙学配有し，ブニによる被害状況をし らべを結果学第5表に示した。

この結果から標準的なブニによる刺咬と被害の状況を

第 5 表 ブュによる被害状況

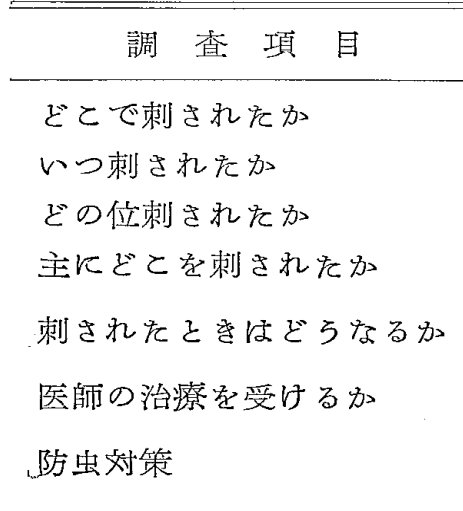

調 查 結 果

屋外 $84.8 \%$, 屋内 $15.2 \%$

夕 $64.9 \%$, 夜 $15.9 \%$, 朝 $13.2 \%$, 昼 $6.0 \%$

数匹 $58.4 \%$, 多数 $29.4 \%, 1$ 匹 $12.2 \%$

足 $38.9 \%$, 手 $37.5 \%$, その他 $15.5 \%$, 顔 $8.1 \%$

は水る $54.9 \%$ ，仕机ない $33.5 \%$ ，うむ $11.7 \%$

かゆ、 $74.4 \%$ ，あまりからない $25.6 \%$

受けない $97.8 \%$ ，受ける $2.2 \%$

何8しない $33.5 \%$ ，作業時手足を被 5 $27.4 \%$,

手足に薬を塗る $24.9 \%$ ，煙をたく $14.2 \%$ 


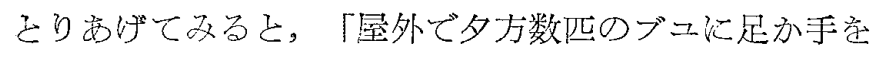
测され，西とが你れてからいが医師の治療もうけない

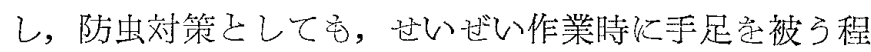
度」ということ炡る。

又，ての結果导通覽すると，1）屋内ですかなりブニ 《刺されている $(15.2 \%)$ とと，2）朝刺される例が案 外少く，逆に夜刺される例が朝小り多いこ己(もつ己も 夕と夜の区㣍汸あいまいである）3）ブ二に则されても はれない人が $33.45 \%$ れるととは，免疫の存在を暗示 している，な扮，防虫対策については，手足俰楽家整る

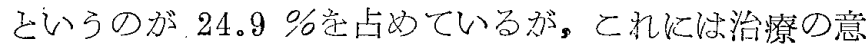

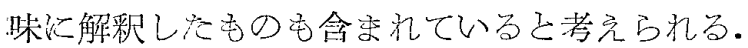

\section{IV 総 括}

1. 新潟県妙高从原飞招小て，50\% D D 水和剂及心 40\% D D Tペースト（リンデン 1.6\%含有）学用い，先

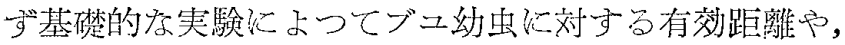
その流失時間空求め，ついで地域的なブ二の駆除作業を 実験的に行い，その效果定与論調查によつて求文た。

2. 基楚的実験办ら得られた結果以次の通りである。

a) 1 分間流水量住対してDDTとして $1.2 \mathrm{ppm}$ 亿

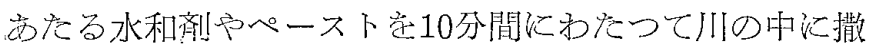
布した場含，S. aokii 户 S. uchidai 飞詨方有效距離 格 800 1,000 mであつた.

b) 同一のDDT量にあたる薬剂学撒布した場合。ペ 一下下学用い方方が水和剂学用いた場合上り，S. aokii 幼出の流失㭙間がはやい。

c) D D T瀑度の刘数に逆比例して，直線的飞流失時 間方短亦くなる。

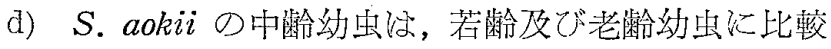
して，D D T撒布の場合に流失㭙閒が長い。

e) S. japonicum 幼虫㳻，S. aokii 幼虫飞比較して DDTに対劣当抵抗が大きいように見受けられる。

3。地域的な駆除実験办ら得られ它結果々次の通りで 就尚。

a)炒高ふ原地域に招いて採集されてブユの種類柱11 種であつた。

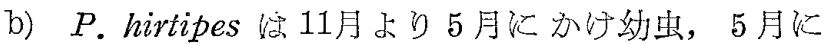

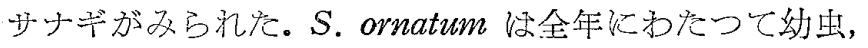

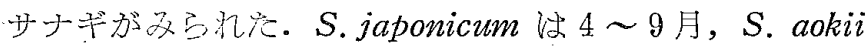

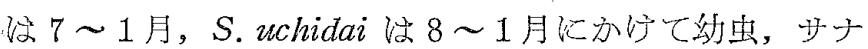

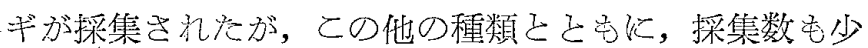
く全貌学つ加起事出来な加た。

c) 炒高原地域に招いて，1955年5月办ら11月に至

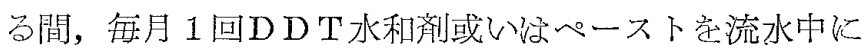
撒有して,ブZ幼虫の駆除字行つた。

d）与論調榃の結果, ブコに刺された人の率は，5月 31日及び7月16日の調查の何㣗に㧤いてす, 奏施地区で 泳実施地区に比較して有意に小さい。又，9月28日の 調查では，ブニによる刺咬数の平均值が，実施地区に款

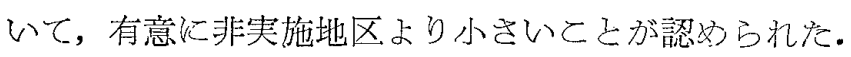

\section{交 献}

1）緒方一竟, 佐々学(1955):日本産ブユ科 Simuliidae の種の検索表々薬骩によるブニ幼虫の駆除法につい て, 䲞生動物 6(1) : 10-18, 一-2) 緒方一喜, 佐々学, 鈴木猛 (1956)：ブユとその駆除，衛生害虫叢書 V. 162 pp. DDT 協会. 一3) 鈴木猛, 緒力一喜, 林滋生, 佐々学他 (1954)：DDT 製剂によるブ二幼虫駆除法の 研究, 環境衞生 $\mathbb{1}(9) ：$ 10-15。一- - 吉田幸雄, 佐藤 淳夫，正垣幸男他 (1956)：京都地方に於けるブニの 研究 (1955年の战績) (ブュ I), 京都医誌 7 (3) : 104110. 一5) 新潟県環境衞生研究会編 (1954)：ブ二駆 除笑施要領 $18 \mathrm{pp}$.

\section{Summary}

The studies on the control of blackflies or Simuliidae were carried out in Myoko Mountain Area, a part of the National Park of North Honshu. Fifty percent DDT wettable powder and $40 \%$ DDT paste containing $1.6 \%$ lindane were used in these experiments.

The larvae of Simulium aokii and S. uchidai were found to be erradicated for the distances of 800 to 1,000 meters along the stream when $1.2 \mathrm{ppm}$ of DDT was applied for 10 minutes. The time required for the detachment of larvae from their habitats were found to be shorter in the cases of DDT paste, and was correlated with amount of DDT applied. Third and 4 th stage larvae of $S$. aokii resisted for longer periods to the insecticide than in younger or older stages. Larvae of S. japonicum were found to be more resistant than other species.

A total of 11 species of Simuliidae were collected from this area. Their areal and seasonal distributions were observed through extensive surveys made over a year's period. The control of blackflies was made on the resort area of 24 square kilometers covering about 50 streams which bred the larvae. DDT paste and wettable powder were applied to the streams by the ratio of $10 \mathrm{ppm}$ of the effective agents against the water amount flowing in a minute. The applications of the insecticides were made by the interval of a month, seven times from May to December. A total of about $76 \mathrm{~kg}$ of paste and $4.8 \mathrm{~kg}$ of wettable powder was consumed during this period.

Remarkable decrease of the larvae as well as the adults of blackflies could be attained through these control works. Almost all of the streams running through this area became free from larvae, and the damages caused by the biting of adults in the summer season were found to be much lower than in the preceding year. 